Article

\title{
Novel Benzothiazole, Benzimidazole and Benzoxazole Derivatives as Potential Antitumor Agents: Synthesis and Preliminary in Vitro Biological Evaluation
}

\author{
Pu Xiang ${ }^{\dagger}$, Tian Zhou ${ }^{\dagger}$, Liang Wang, Chang-Yan Sun, Jing Hu, Ying-Lan Zhao * and Li Yang * \\ State Key Laboratory of Biotherapy and Cancer Center, West China Hospital, \\ West China Medicinal School, Sichuan University, Chengdu 610041, Sichuan, China \\ $\dagger$ These authors contributed equally to this work. \\ * Authors to whom correspondence should be addressed; E-Mails: Alancenxb@sina.com (Y.-L.Z.); \\ yangli@scu.edu.cn (L.Y.); Tel.: +86-28-8550-3628; Fax: +86-28-8550-3628.
}

Received: 12 December 2011; in revised form: 6 January 2012 / Accepted: 10 January 2012 / Published: 17 January 2012

\begin{abstract}
In a previous hit-to-lead research program targeting anticancer agents, two promising lead compounds, $\mathbf{1} \mathbf{a}$ and $\mathbf{1 b}$, were found. However, the poor solubility of $\mathbf{1 a}$ and 1b made difficult further in vivo studies. To solve this problem, a lead optimization was conducted through introducing $N$-methyl-piperazine groups at the 2-position and 6-position. To our delight, the optimized analogue 1d showed comparable antiproliferative activity in vitro with better solubility, compared with 1a. Based on this result, the replacement of the benzothiazole scaffold with benzimidazole and benzoxazole moieties afforded $\mathbf{1 f}$ and $\mathbf{1 g}$, whose activities were fundamentally retained. In the preliminary in vitro biological evaluation, the immunofluorescence staining of HCT116 cells indicated that 1d, 1f and 1g led to cytosolic vacuolization which was not induced by $1 \mathrm{a}$ at low micromolecular concentrations. These results suggest that these optimized compounds might potentially constitute a novel class of anticancer agents, which merit further studies.
\end{abstract}

Keywords: benzothiazole derivatives; benzimidazole; benzoxazole; antitumor; cytosolic vacuolization 


\section{Introduction}

Cancer is the leading cause of death in developed countries and the second leading cause of death in developing countries [1]. Although surgical resection is potentially curative, the risk of recurrence remains very high. Besides surgical resection, treatment strategies for high risk patients are still mainly based on adjuvant or neoadjuvant use of chemotherapeutic agents alone or in combination with radiotherapy. Unfortunately, the use of the above standard therapeutic protocols only results in a moderate decline in mortality and the risk of sustaining a recurrence of disease remains high. Thus, it is urgent to develop novel chemotherapeutic agents for the treatment of cancer. In a recent hit-to-lead research of anticancer agents [2], lead compounds $\mathbf{1 a}$ and $\mathbf{1 b}$ (Figure 1) with benzothiazole scaffolds, showed promising anticancer in vitro activities. However, the solubility of $\mathbf{1 a}$ and $\mathbf{1 b}$ was far from satisfactory for further in vivo research. As a result, a lead optimization of $\mathbf{1 a}$ and $\mathbf{1 b}$ was conducted.

Figure 1. The structure of lead compounds $\mathbf{1 a}$ and $\mathbf{1 b}$.<smiles>[R]C(=O)Nc1ccc2nc(SCC(=O)NCc3ccc([R])cc3)sc2c1</smiles>

1a: $\mathrm{R}_{1}=\mathrm{Cl}, \mathrm{R}_{2}=2$-Methoxyphenyl

1b: $\mathrm{R}_{1}=\mathrm{H}, \mathrm{R}_{2}=$ chloromethyl

The $N$-methyl-piperazine group as found in imatinib is a commonly used motif in lead optimization [3]. Introduction of $\mathrm{N}$-methylpiperazine moieties at the 2-position and 6-positions of the benzothiazole scaffold afforded compounds 1c, 1d and 1e. To determine the role of the benzothiazole scaffold, the benzoxazole analogue $\mathbf{1 f}$ and benzimidazole analogue $\mathbf{1 g}$ were also designed (Figure 2).

Figure 2. The structures of compounds $1 \mathbf{c}-\mathbf{g}$.<smiles>[R]C(=O)Nc1ccc2nc(SCC(=O)Nc3ccc(N4CCN(C)CC4)cc3)sc2c1</smiles><smiles>CN1CCN(c2ccc(C(=O)Nc3ccc4nc(SCC(=O)NCc5ccc(Cl)cc5)sc4c3)cc2)CC1</smiles>

1d $X=S$, if $X=N, 1 g X=O, R=2-M e t h o x y p h e n y l$

Herein, we report the synthesis of $\mathbf{1} \mathbf{c}-\mathbf{g}$, preliminary structure-activity relationships (SARs) and biological evaluation of these anticancer agents.

\section{Results and Discussion}

\subsection{Chemistry}

The synthetic route of compounds $\mathbf{1} \mathbf{c}-\mathbf{g}$ using a modified literature method [4,5] is outlined in Scheme 1. Taking 1d for example, the key intermediate 2a, 2-mercapto-6-aminobenzothiazole, was 
alkylated with side chain $\mathbf{3 b}$ under basic conditons to give 4a. Subsequent acylation of $\mathbf{4 a}$ with 2-methoxybenzoic acid yielded the target compound 1d. Besides the optimization of side chains, the replacement of the benzothiazole scaffold with benzimidazole and benzoxazole units (Table 1), afforded $1 \mathbf{f}$ and $\mathbf{1 g}$ which were prepared using the same synthetic strategy.

Scheme 1. General procedures for the synthesis of 1c-g.

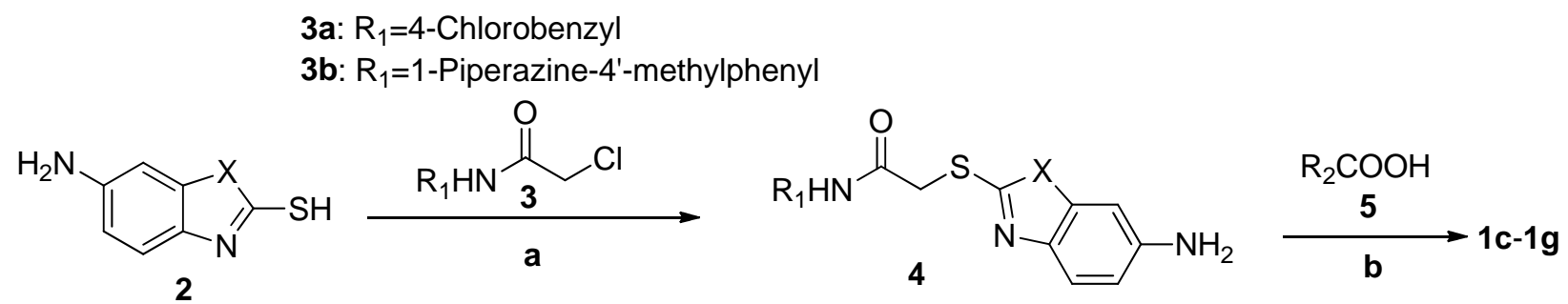

2a: $X=S ; 2 b: X=N H ; 2 c: X=O$

4a: R1=1-Piperazine-4'-methylphenyl, $X=S$

4b: R1=1-Piperazine-4'-methylphenyl, $X=\mathrm{NH}$

4c: R1=1-Piperazine-4'-methylphenyl, $X=0$

4d: R1=4-Chlorobenzyl, $X=S$;

Reagents and conditions: (a): 3, $\mathrm{K}_{2} \mathrm{CO}_{3}$, acetone, reflux, 3-4 h, 80-98\%; (b): $\mathrm{ClCH}_{2} \mathrm{COCl}, \mathrm{CH}_{2} \mathrm{Cl}_{2}$, r.t., $0.5 \mathrm{~h}, 95 \%$ for $\mathbf{1 c} ; \mathbf{5}$, EDCI, HOBt, DIPEA, DMF, $80{ }^{\circ} \mathrm{C}, 4-8 \mathrm{~h}, 60-70 \%$ for $\mathbf{1 d}-\mathbf{g}$.

Table 1. The anti-proliferative activity of $\mathbf{1 a - g}$ against HepG2 and HCT-116 cells.

\begin{tabular}{|c|c|c|c|c|c|}
\hline \multirow{2}{*}{ Compound } & \multirow{2}{*}{$\mathbf{R}_{1}$} & \multirow{2}{*}{$\mathbf{R}_{2}$} & \multirow{2}{*}{$\mathbf{X}$} & \multicolumn{2}{|c|}{$I C_{50}(\mu M)^{a}$} \\
\hline & & & & HepG2 & HCT-116 \\
\hline $1 \mathbf{a}$ & 4-Chlorobenzyl & 2-Methoxyphenyl & $\mathrm{S}$ & 0.64 & 1.52 \\
\hline $1 \mathbf{b}$ & Benzyl & Chloromethyl & $\mathrm{S}$ & 1.13 & 1.16 \\
\hline $1 \mathrm{c}$ & $\begin{array}{c}N \text {-methyl- } \\
\text { piperazine-phenyl }\end{array}$ & Chloromethyl & $\mathrm{S}$ & $>40.0$ & $>40.0$ \\
\hline 1d & $\begin{array}{l}N \text {-methyl- } \\
\text { piperazine-phenyl }\end{array}$ & 2-Methoxyphenyl & $\mathrm{S}$ & 2.10 & 1.25 \\
\hline 1e & 4-Chlorobenzyl & $\begin{array}{c}N \text {-methylpiperazine- } \\
\text { phenyl }\end{array}$ & $\mathrm{S}$ & 31.2 & 28.8 \\
\hline 1f & $\begin{array}{c}N \text {-methyl- } \\
\text { piperazine-phenyl }\end{array}$ & 2-Methoxyphenyl & $\mathrm{N}$ & 14.6 & 3.69 \\
\hline $1 g$ & $\begin{array}{c}N \text {-methyl- } \\
\text { piperazine-phenyl }\end{array}$ & 2-Methoxyphenyl & $\mathrm{O}$ & 12.2 & 2.61 \\
\hline
\end{tabular}

${ }^{a}$ The cytotoxicity effects of various compounds on cancer cells were determined by the MTT assay, and the results were expressed as the mean $\mathrm{IC}_{50}$ calculated from three independent experiments.

The key intermediate $\mathbf{2 c}$ was readily prepared from commercially available 2-amino-5-nitrophenol following cyclization and subsequent reduction of the nitro group according to the method represented in Scheme 2. 
Scheme 2. Synthesis of 6-aminobenzofuran-2-thiol 2c.

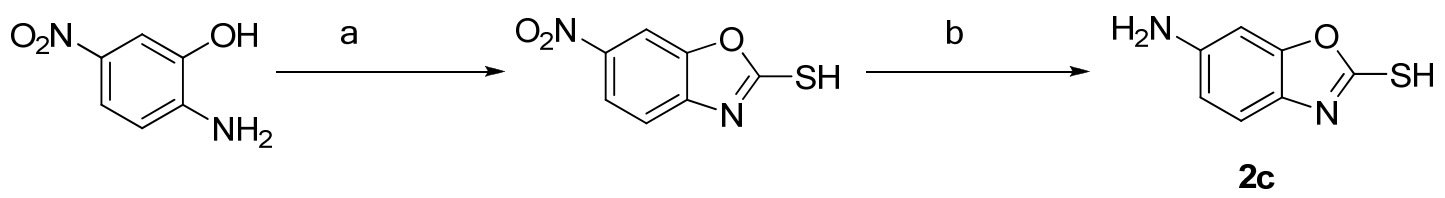

Reagents and conditions: (a): Potassium ethylxanthate, pyridine, $6 \mathrm{~h}, 110^{\circ} \mathrm{C}, 97 \%$; (b): $\mathrm{Fe}, \mathrm{NH}_{4} \mathrm{Cl}$, ethanol/water, $90-95^{\circ} \mathrm{C}, 1 \mathrm{~h}, 95 \%$.

Side chain $\mathbf{3 b}$ was prepared from 4-fluoronitrobenzene condensed with $N$-methylpiperazine, subsequent reduction and acylation as shown in Scheme 3.

Scheme 3. Synthesis of 2-chloro- $N$-(4-(4-methylpiperazin-1-yl)phenyl)acetamide $\mathbf{3 b}$.

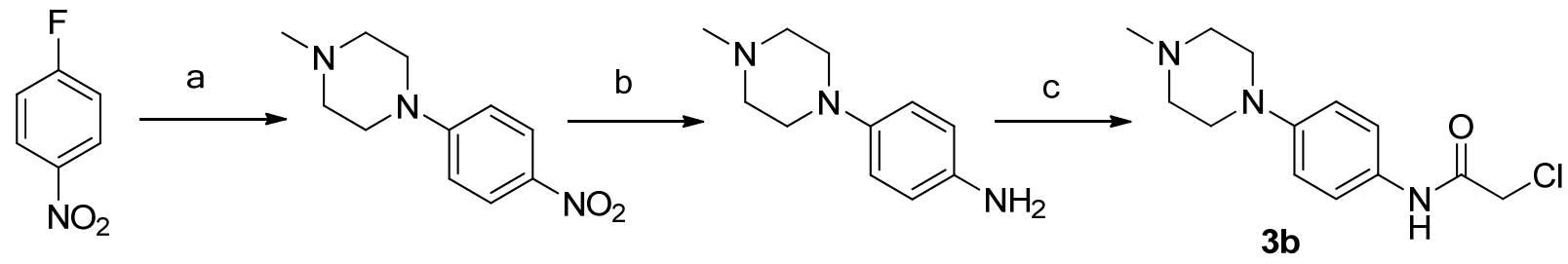

Reagents and conditions: (a): $\mathrm{N}$-methylpiperazine, r.t., 0.5 h, $99 \%$; (b): $\mathrm{Fe}, \mathrm{NH}_{4} \mathrm{Cl}$, ethanol/water, 90-95 ${ }^{\circ} \mathrm{C}, 0.5-1$ h, $95-98 \%$; (c): $\mathrm{ClCH}_{2} \mathrm{COCl}_{2} \mathrm{CH}_{2} \mathrm{Cl}_{2}$, r.t., 0.5 h, $90 \%$.

\subsection{The MTT Assay}

With 1c-g at hand, we evaluated their anti-proliferative activities $\left(\mathrm{IC}_{50}\right)$ on HepG2 and HCT116 cells, using the MTT assay (Table 1). As shown in the Table, introduction of an $N$-methylpiperazine substituent at the 2-position (compound 1d) in the R1 group was well tolerated. To our surprise, replacement of the benzyl group in R1 with an $N$-methylpiperazine-phenyl group (compound 1c) led to almost total loss of activity. The introduction of $N$-methylpiperazine substituent at the 6-position (1e) in the R2 group had a detrimental effect on the potency, that is, about 20-50-fold decrease in potency, compared with that of 1a. After identifying that the $N$-methylpiperazine-phenyl substituent is well tolerated at the 2-position in the R1 group, we next turned to examining the role of the benzothiazole scaffold. Replacement of the benzothiazole ring with benzimidazole and benzoxazole yielded 1f and $1 \mathrm{~g}$ with a slightly decrease in potency for HCT-116 cells compared with 1a, but showed no clear SAR trends. It was noteworthy that analogue $\mathbf{1 d}$ exhibited comparable inhibitory activity against HepG2 and HCT-116 cells.

To further study the cytotoxic profile, compound 1d was selected for evaluation of inhibitory activities against a panel of different types of human cancer cell lines: Prostate cancer cell line PC-3, human cervical carcinoma cell line Hela, ovarian cancer cell line SKOV-3, lung cancer cell line A549, melanoma cell line A375, nonsmall cell lung cancer cell line H460 and epithelial cancer cell line A431 (Table 2). As shown in Table 2, compound 1d also showed broad-spectrum inhibitory activity which was exhibited in previous research [2]. Some $\mathrm{IC}_{50}$ values were better than $\mathbf{1 a}$, such as against Hela and SKOV-3 cells. 
Table 2. The anti-proliferative activities of $\mathbf{1 d}$ against various cancer cell lines.

\begin{tabular}{cccccccc}
\hline \multirow{2}{*}{ Compound } & \multicolumn{7}{c}{$\mathbf{I C}_{\mathbf{5 0}}(\boldsymbol{\mu M})^{\mathbf{a}}$} \\
\cline { 2 - 8 } & $\mathbf{P C - 3}$ & Hela & SKOV-3 & $\mathbf{A 5 4 9}$ & $\mathbf{A 3 7 5}$ & H460 & A431 \\
\hline 1a & 1.3 & 4.5 & 6.2 & 1.9 & 2.2 & 2.3 & 1.3 \\
1d & 1.2 & 1.5 & 1.3 & 1.1 & 2.3 & 1.8 & 2.5 \\
\hline
\end{tabular}

${ }^{\mathrm{a}}$ The cytotoxicity effects of compounds on cancer cells were determined by the MTT assay, and the results were expressed as the mean $\mathrm{IC}_{50}$ calculated from three independent experiments.

\subsection{The Solubility Assay}

The optimized analogues 1d, $\mathbf{1 f}$ and $\mathbf{1 g}$ showed comparable anti-proliferative activities in vitro compared with 1a. To conduct a preliminary assessment of the absorption in vivo, solubility was further determined (Table 3). As shown in Table 3, 1d, 1f and $\mathbf{1 g}$ showed better solubility both in ethanol and water after the introduction of $N$-methylpiperazine group.

Table 3. The solubility of compound $\mathbf{1 a}, \mathbf{1 d}, \mathbf{1 f}$ and $\mathbf{1 g}$.

\begin{tabular}{ccccc}
\hline Solvent $(\boldsymbol{\mu g} / \mathbf{m L})$ & $\mathbf{1 a}$ & $\mathbf{1 d}$ & $\mathbf{1 f}$ & $\mathbf{1 g}$ \\
\hline ethanol & 1.77 & 317.9 & 2803 & 572.2 \\
water & 0.093 & 5.99 & 981.7 & 548.4 \\
\hline
\end{tabular}

\subsection{Immunofluorescence Staining}

In our previous research, it was found that 1a could induce apoptosis of cancer cells. To further study the antitumor mechanisms of 1a, 1d, 1f and $\mathbf{1 g}$ in vitro, an immunofluorescence staining of HCT116 cells was conducted (Figure 3 ).

Figure 3. The immunofluorescence staining of 1a, 1d, $1 \mathbf{f}$ and $\mathbf{1 g}$ on HCT-116 cells for $24 \mathrm{~h}$. Blue: nuclear; Green: tubulin.

1a. $2 \mu \mathrm{M}$

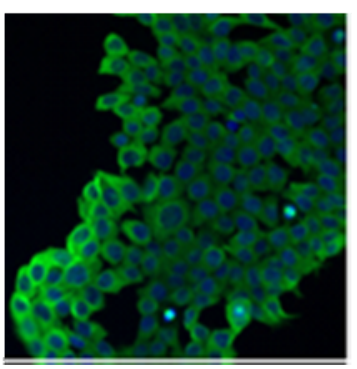

$1 d, 1 \mu M \mid$

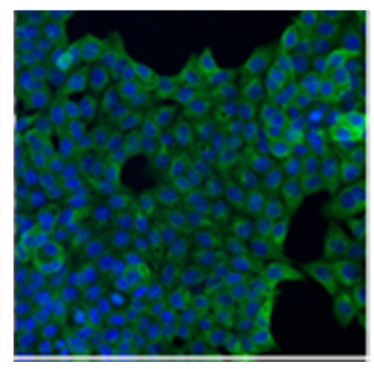

1f. 4 plvi

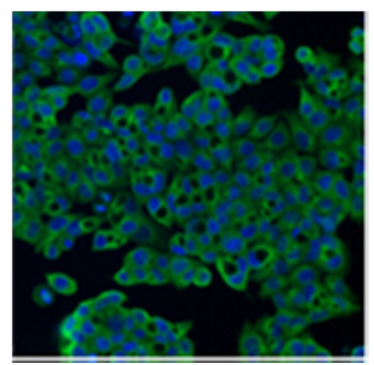

18. $3 \mu \mathrm{M}$

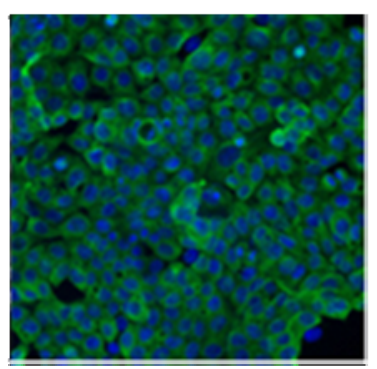

As shown in Figure 3, the tubulin of HCT-116 cells was intact after the treatment with 1d, $\mathbf{1 f}$ and $\mathbf{1 g}$. However, cytosolic vacuolization appeared, which was't observed for 1a. It has been reported that this kind of cytosolic vacuolization is related with the inhibition of HSP-90 protein or the proteasome-promoted protein ubiquitination [6]. Further mechanistic studies are currently in progress. 


\section{Experimental}

\subsection{General}

The human cancer cell lines, HepG2, HCT116, PC-9, Hela, SKOV-3, A549, A375, H460 and A431 were purchased from the American Type Culture Collection (ATCC, Rockville, MD, USA). Dulbecco's modified Eagle medium (DMEM) and RPMI 1640 were purchased from Gibco (Grand Island, NY, USA). Fetal bovine serum (FBS) was obtained from Hyclone (Logan, UT, USA). The purity of compound screened in biological assays was determined to be $>98 \%$ by HPLC analysis. An Symmetry $\mathrm{C}_{18}(75 \mathrm{~mm} \times 4.6 \mathrm{~mm}$, i.d. $3.5 \mu \mathrm{m})$ (Waters, Milford, MA, USA) was used with a t elution of acetonitrile and HPLC-grade water as mobile phase. ${ }^{1} \mathrm{H}-\mathrm{NMR}$ were recorded at $400 \mathrm{MHz}$ on a Varian spectrometer (Varian, Palo Alto, CA, USA) model Gemini 400. Mass Spectra (MS) were measured by Q-TOF Priemier mass spectrometer utilizing electrospray ionization (ESI) (Micromass, Manchester, UK).

\subsection{Preparation of 6-Aminobenzo[d]oxazole-2-thiol (2c)}

\subsubsection{6-Nitrobenzo[d]oxazole-2-thiol}

6-Nitrobenzo[d]oxazole-2-thiol was synthesized according to a modified literature method [7]. A suspension of 2-amino-5-nitrophenol (3.08 g, $20 \mathrm{mmol})$ and potassium ethylxanthate $(3.36 \mathrm{~g}, 21 \mathrm{mmol})$ in dry pyridine $(40 \mathrm{~mL})$ was stirred at $120^{\circ} \mathrm{C}$ for $6 \mathrm{~h}$, and then at room temperature for another $16 \mathrm{~h}$. $2 \mathrm{M} \mathrm{HCl}$ solution was added to the solution to adjust the $\mathrm{pH}$ value to 6 . The resulting precipitate was collected by filtration, washed with petroleum ether and then dried in vacuum to afford $3.22 \mathrm{~g} \mathrm{(97 \% )}$ of the title compound. ${ }^{1} \mathrm{H}-\mathrm{NMR}$ (DMSO- $\left.d_{6}\right) \delta: 7.39(\mathrm{~d}, 1 \mathrm{H}, J=8 \mathrm{~Hz}), 7.86(\mathrm{t}, 1 \mathrm{H}, J=8 \mathrm{~Hz}), 8.22(\mathrm{dd}$, $\left.\left.1 \mathrm{H}, J_{1}=4 \mathrm{~Hz}, J_{2}=8 \mathrm{~Hz}\right)\right), 8.41(\mathrm{~s}, 1 \mathrm{H})$. ESI-MS $(\mathrm{m} / \mathrm{z}, \%): 197.1(\mathrm{M}+\mathrm{H})^{+}$.

\subsubsection{6-Aminobenzo[d]oxazole-2-thiol (2c)}

A mixture of 6-nitrobenzo[d]oxazole-2-thiol (5 g, $25 \mathrm{mmol})$, iron powder $(3.36 \mathrm{~g}, 60 \mathrm{mmol})$, and ammonium chloride $(2.67 \mathrm{~g}, 50 \mathrm{mmol})$ was refluxed in a mixed solvent of ethanol $(25 \mathrm{~mL})$ and $\mathrm{H}_{2} \mathrm{O}$ $(8 \mathrm{~mL})$. After completion of the reaction, the mixture was filtered while hot and washed with petroleum ether. Standing at room temperature gave compound $\mathbf{2 c}$ as a bright yellow solid. Yield: $3.7 \mathrm{~g}$, 90\%. ${ }^{1} \mathrm{H}-\mathrm{NMR}\left(\mathrm{DMSO}-\mathrm{d}_{6}\right) \delta: 6.51\left(\mathrm{dd}, 2 \mathrm{H}, J_{1}=4 \mathrm{~Hz}, J_{2}=8 \mathrm{~Hz}\right), 6.64(\mathrm{~d}, 2 \mathrm{H}, J=4 \mathrm{~Hz}), 6.90(\mathrm{~d}, 2 \mathrm{H}$, $J=8 \mathrm{~Hz})$. ESI-MS $(\mathrm{m} / \mathrm{z}, \%): 167.1(\mathrm{M}+\mathrm{H})^{+}$.

\subsection{2-Chloro-N-(4-chlorobenzyl)acetamide (3a)}

2-Chloroacetyl chloride $(4.79 \mathrm{~g}, 42 \mathrm{mmol})$ was added dropwise with stirring to a mixture of (4-chlorophenyl) methanamine $(4.96 \mathrm{~g}, 35 \mathrm{mmol})$ in dichloromethane $(50 \mathrm{~mL})$ cooled to $0{ }^{\circ} \mathrm{C}$. The resulting mixture was allowed to warm to ambient temperature and stirred for $1 \mathrm{~h}$. After filtering, the solid was washed with petroleum ether and dried under vacuum for $12 \mathrm{~h}$ at $25-30{ }^{\circ} \mathrm{C}$. The title compound 3a was obtained by recrystalization from ethanol. Yield: $7.25 \mathrm{~g}, 95 \% .{ }^{1} \mathrm{H}-\mathrm{NMR}$ (400 MHz, 
DMSO-d $\left.)_{6}\right) \delta 4.13(\mathrm{~s}, 2 \mathrm{H}), 4.29(\mathrm{~d}, J=6.0 \mathrm{~Hz}, 2 \mathrm{H}), 7.28(\mathrm{~d}, J=4.4 \mathrm{~Hz}, 2 \mathrm{H}), 7.39(\mathrm{~d}, J=8.0 \mathrm{~Hz}, 2 \mathrm{H})$, $8.77(\mathrm{~s}, 1 \mathrm{H})$. ESI-MS $(\mathrm{m} / \mathrm{z}, \%): 218.0(\mathrm{M}-\mathrm{H})^{+}$.

\subsection{2-Chloro-N-(4-(4-methylpiperazin-1-yl)phenyl)acetamide (3b)}

\subsubsection{1-Methyl-4-(4-nitrophenyl)piperazine}

Briefly, 1-methylpiperazine $(15.6 \mathrm{~g}, 156 \mathrm{mmol})$ was added slowly while stirring to a solution of 4-fluoronitrobenzene $(20 \mathrm{~g}, 142 \mathrm{mmol})$ at room temperature. The mixture was stirred for $1 \mathrm{~h}$, then filtered and washed with petroleum ether to give product as an orange solid. Yield: $30.3 \mathrm{~g}, 96.43 \%$. ${ }^{1} \mathrm{H}-\mathrm{NMR}$ (DMSO-d $) \delta: 2.22(\mathrm{~s}, 3 \mathrm{H}), 2.43(\mathrm{t}, 4 \mathrm{H}, J=4 \mathrm{~Hz}), 3.45(\mathrm{t}, 4 \mathrm{H}, J=4 \mathrm{~Hz}), 7.03$ (d, 2H, $\left.J=8 \mathrm{~Hz}\right)$, $8.05(\mathrm{~d}, 2 \mathrm{H}, \mathrm{J}=8 \mathrm{~Hz})$. ESI-MS ( $\mathrm{m} / \mathrm{z}, \%): 222.0(\mathrm{M}+\mathrm{H})^{+}$.

\subsubsection{4-(4-Methylpiperazin-1-yl)aniline}

A mixture of 1-methyl-4-(4-nitrophenyl) piperazine (14.8 g, $67 \mathrm{mmol})$, iron powder (15 g, $268 \mathrm{mmol})$, ammonium chloride (7.2 g, $134 \mathrm{mmol})$ was refluxed in a mixed solvent of ethanol $(60 \mathrm{~mL})$ and $\mathrm{H}_{2} \mathrm{O}$ $(20 \mathrm{~mL})$. After completion of the reaction, the mixture was filtered while hot and washed with petroleum ether. After standing at room temperature an off-white acicular solid was obtained. Yield: $12.2 \mathrm{~g}, 95.31 \%$. ${ }^{1} \mathrm{H}-\mathrm{NMR}\left(\mathrm{DMSO}-d_{6}\right) \delta: 2.22(\mathrm{~s}, 3 \mathrm{H}), 2.5(\mathrm{t}, 4 \mathrm{H}, J=4 \mathrm{~Hz}), 2.75(\mathrm{t}, 4 \mathrm{H}, J=4 \mathrm{~Hz}), 3.22$ $(\mathrm{s}, 2 \mathrm{H}), 6.55(\mathrm{~d}, 2 \mathrm{H}, J=8 \mathrm{~Hz}), 6.74(\mathrm{~d}, 2 \mathrm{H}, J=8 \mathrm{~Hz})$. ESI-MS $(\mathrm{m} / \mathrm{z}, \%): 192.0(\mathrm{M}+\mathrm{H})^{+}$.

\subsubsection{2-Chloro-N-(4-(4-methylpiperazin-1-yl)phenyl)acetamide (3b)}

2-Chloroacetyl chloride $(4.79 \mathrm{~g}, 42 \mathrm{mmol})$ was added dropwise with stirring to a mixture of 1-methyl-4-(4-nitrophenyl) piperazine $(6.69 \mathrm{~g}, 35 \mathrm{mmol})$ in dichloromethane $(50 \mathrm{~mL})$ cooled at $0{ }^{\circ} \mathrm{C}$. The resulting mixture was allowed to warm to ambient temperature and stirred for $1 \mathrm{~h}$. After filtering, the solid was washed with petroleum ether and dried under vacuum for $12 \mathrm{~h}$ at $25-30{ }^{\circ} \mathrm{C}$. The title compound $\mathbf{3 b}$ was obtained by recrystalization from a solution of ethanol. Yield: $8.48 \mathrm{~g}, 90.51 \%$. ${ }^{1} \mathrm{H}-\mathrm{NMR}\left(\mathrm{DMSO}-d_{6}\right) \delta: 2.21(\mathrm{~s}, 3 \mathrm{H}), 2.43(\mathrm{t}, 4 \mathrm{H}, J=4.8 \mathrm{~Hz}), 3.07(\mathrm{t}, 4 \mathrm{H}, J=4.8 \mathrm{~Hz}), 4.2(\mathrm{~s}, 2 \mathrm{H})$, $6.90(\mathrm{~d}, 2 \mathrm{H}, J=8 \mathrm{~Hz}), 7.42(\mathrm{~d}, 2 \mathrm{H}, J=8 \mathrm{~Hz}), 10.10(\mathrm{~s}, 1 \mathrm{H})$. ESI-MS $(\mathrm{m} / \mathrm{z}, \%): 268.1(\mathrm{M}+\mathrm{H})^{+}$.

\subsection{General Procedure for Preparing Compounds 4a-d}

Compound 3a-b $(13.76 \mathrm{mmol})$ was added to a mixture of $\mathbf{2 a}-\mathbf{c}(16.51 \mathrm{mmol})$ and potassium carbonate $(20.64 \mathrm{mmol})$ in acetone $(25 \mathrm{~mL})$ while refluxing with stirring. The resulting mixture was stirred under reflux for $4 \mathrm{~h}$, then cooled to ambient temperature. After removal of acetone on a rotary evaporator, the solid was dissolved in ethyl acetate $(100 \mathrm{~mL})$ and washed with water $(2 \times 10 \mathrm{~mL})$, saturated solution of sodium bicarbonate $(2 \times 20 \mathrm{~mL})$ and sodium chloride $(2 \times 20 \mathrm{~mL})$. Then, the organic phase was dried over $\mathrm{Na}_{2} \mathrm{SO}_{4}$ and concentrated in vacuo to give a solid product. The title compounds 4a-d were thus obtained, and could be used directly for the next step without further purification. The yields of $\mathbf{4 a}, \mathbf{4 b}, \mathbf{4} \mathbf{c}$ and $\mathbf{4 d}$, were $92 \%, 90 \%, 90 \%$ and $93 \%$, respectively.

2-(6-aminobenzo[d] thiazol-2-ylthio)-N-(4-(4-methylpiperazin-1-yl)phenyl)acetamide (4a): ${ }^{1} \mathrm{H}-\mathrm{NMR}$ $\left(\mathrm{DMSO}_{6}\right) \delta: 2.24(\mathrm{~s}, 3 \mathrm{H}), 2.44(\mathrm{t}, 4 \mathrm{H}, J=4 \mathrm{~Hz}), 3.06(\mathrm{t}, 4 \mathrm{H}, J=4 \mathrm{~Hz}), 4.14(\mathrm{~s}, 2 \mathrm{H}), 5.38(\mathrm{~s}, 2 \mathrm{H})$, 
$6.70\left(\mathrm{dd}, 1 \mathrm{H}, J_{1}=2 \mathrm{~Hz}, J_{2}=8.8 \mathrm{~Hz}\right), 6.88(\mathrm{~d}, 2 \mathrm{H}, J=9.2 \mathrm{~Hz}), 7.00(\mathrm{~d}, 1 \mathrm{H}, J=2.4 \mathrm{~Hz}), 7.41(\mathrm{~d}, 2 \mathrm{H}$, $J=8.8 \mathrm{~Hz}), 7.49(\mathrm{~d}, 1 \mathrm{H}, J=8.8 \mathrm{~Hz}), 10.16(\mathrm{~s}, 1 \mathrm{H})$. ESI-MS $(\mathrm{m} / \mathrm{z}, \%): 414.2(\mathrm{M}+\mathrm{H})^{+}$.

2-(6-amino-1H-benzo[d]imidazol-2-ylthio)-N-(4-(4-methylpiperazin-1-yl)phenyl)acetamide (4b): ${ }^{1} \mathrm{H}-\mathrm{NMR}$ $\left(\mathrm{DMSO}_{6}\right) \delta: 2.23(\mathrm{~s}, 3 \mathrm{H}), 2.47(\mathrm{~s}, 4 \mathrm{H}), 3.07(\mathrm{~s}, 4 \mathrm{H}), 4.21(\mathrm{~s}, 2 \mathrm{H}), 5.31(\mathrm{~s}, 2 \mathrm{H}), 6.46(\mathrm{~d}, 1 \mathrm{H}, J=4 \mathrm{~Hz})$, $6.56(\mathrm{~s}, 1 \mathrm{H}), 6.88(\mathrm{~d}, 2 \mathrm{H}, J=8.8 \mathrm{~Hz}), 7.16(\mathrm{~s}, 1 \mathrm{H}), 7.42(\mathrm{~d}, 2 \mathrm{H}, J=8.8 \mathrm{~Hz}), 10.40(\mathrm{~s}, 1 \mathrm{H}), 12.13(\mathrm{~s}, 1 \mathrm{H})$. ESI-MS $(\mathrm{m} / \mathrm{z}, \%): 397.3(\mathrm{M}+\mathrm{H})^{+}$.

2-(6-aminobenzo[d]oxazol-2-ylthio)-N-(4-(4-methylpiperazin-1-yl)phenyl)acetamide (4c): ${ }^{1} \mathrm{H}-\mathrm{NMR}$ $\left(\mathrm{DMSO}_{6}\right) \delta: 2.23(\mathrm{~s}, 3 \mathrm{H}), 2.46(\mathrm{t}, 4 \mathrm{H}, J=4 \mathrm{~Hz}), 3.07(\mathrm{t}, 4 \mathrm{H}, J=4 \mathrm{~Hz}), 4.23(\mathrm{~s}, 2 \mathrm{H}), 5.31(\mathrm{~s}, 2 \mathrm{H})$, $6.56\left(\mathrm{dd}, 1 \mathrm{H}, J_{1}=2 \mathrm{~Hz}, J_{2}=8.4 \mathrm{~Hz}\right), 6.71(\mathrm{~d}, 1 \mathrm{H}, J=1.6 \mathrm{~Hz}), 6.89(\mathrm{~d}, 2 \mathrm{H}, J=8 \mathrm{~Hz}), 7.22(\mathrm{t}, 1 \mathrm{H}, J=8 \mathrm{~Hz})$, $7.41(\mathrm{~d}, 2 \mathrm{H}, \mathrm{J}=8 \mathrm{~Hz}), 10.16(\mathrm{~s}, 1 \mathrm{H})$. ESI-MS (m/z, \%): $398.2(\mathrm{M}+\mathrm{H})^{+}$.

2-(6-aminobenzo[d] thiazol-2-ylthio)- $N$-(4-chlorobenzyl)acetamide (4d): ${ }^{1} \mathrm{H}-\mathrm{NMR}$ (DMSO- $\left.d_{6}\right) \delta: 4.09$ $(\mathrm{s}, 2 \mathrm{H}), 4.30(\mathrm{~d}, 2 \mathrm{H}, J=5.6 \mathrm{~Hz}), 5.40(\mathrm{~s}, 2 \mathrm{H}), 6.73\left(\mathrm{dd}, 1 \mathrm{H}, J_{1}=1.6 \mathrm{~Hz}, J_{2}=8.8 \mathrm{~Hz}\right), 7.01(\mathrm{~d}, 1 \mathrm{H}$, $J=1.6 \mathrm{~Hz}), 7.28(\mathrm{q}, 4 \mathrm{H}, J=8.4 \mathrm{~Hz}), 7.49(\mathrm{~d}, 1 \mathrm{H}, J=8.4 \mathrm{~Hz}), 8.81(\mathrm{t}, 1 \mathrm{H}, J=5.6 \mathrm{~Hz})$. ESI-MS $(\mathrm{m} / \mathrm{z}$, $\%): 364.0(\mathrm{M}+\mathrm{H})^{+}$.

\subsection{2-Chloro-N-(2-(2-(4-(4-methylpiperazin-1-yl)phenylamino)-2-oxoethylthio)benzothiazol-6-yl)- acetamide (1c)}

2-Chloroacetyl chloride (43 $\mathrm{mg}, 0.38 \mathrm{mmol}$ ) was added dropwise with stirring to a solution of $4 \mathbf{a}$ $(80 \mathrm{mg}, 0.19 \mathrm{mmol})$ in dichloromethane $(4 \mathrm{~mL})$ originally at $0{ }^{\circ} \mathrm{C}$. The resulting mixture was allowed to warm to ambient temperature and stirred for $1 \mathrm{~h}$. After filtering, the solid was washed with petroleum ether and dried under vacuum for $12 \mathrm{~h}$ at $25-30{ }^{\circ} \mathrm{C}$. The title compound $1 \mathrm{c}$ (an off-white solid) were obtained by recrystallization from ethanol. Yield: $72 \mathrm{mg}, 77.42 \%$. m.p. $245.8-246.1{ }^{\circ} \mathrm{C}$. ${ }^{1} \mathrm{H}-\mathrm{NMR}\left(\mathrm{DMSO}_{6}\right) \delta: 2.21(\mathrm{~s}, 3 \mathrm{H}), 2.43(\mathrm{t}, J=4.4 \mathrm{~Hz}, 4 \mathrm{H}), 3.07$ (t, 4H, $\left.J=4.8 \mathrm{~Hz}\right), 4.30$ (s, 2H), 4.35 (s, 2H), 6.93 (d, 2H, J=8.8Hz), 7.49 (d, 2H, $J=8.8 \mathrm{~Hz}), 7.55$ (dd, 1H, $J=2 \mathrm{~Hz}, 8.8 \mathrm{~Hz}), 7.79$ (d, $1 \mathrm{H}, J=8.8 \mathrm{~Hz}), 8.39(\mathrm{~d}, 1 \mathrm{H}, J=2 \mathrm{~Hz}), 10.32(\mathrm{~s}, 1 \mathrm{H}), 10.62(\mathrm{~s}, 1 \mathrm{H})$; ESI-MS $(\mathrm{m} / \mathrm{z}, \%): 490.3(\mathrm{M}+\mathrm{H})^{+}$.

\subsection{General Procedure for Preparing Compounds 1d-g}

A mixture of compound $\mathbf{4 a}-\mathbf{d}(0.5 \mathrm{mmol})$, 2-methoxybenzoic acid hydrate or 4-(4-methylpiperazin1-yl)benzoic acid $(0.75 \mathrm{mmol})$, EDCI $(0.75 \mathrm{mmol})$, HOBt $(0.75 \mathrm{mmol})$, DIPEA (0.75 mmol) was warmed up to $80{ }^{\circ} \mathrm{C}$ in $\mathrm{DMF}(5 \mathrm{~mL})$ with stirring. After completion of reaction, the mixture was diluted with ethyl acetate $(100 \mathrm{~mL})$. The resulting mixture was washed with washed with water $(2 \times 20 \mathrm{~mL})$, saturated solution of sodium bicarbonate $(2 \times 20 \mathrm{~mL})$ and sodium chloride $(2 \times 20 \mathrm{~mL})$. Then, the organic phase was dried over $\mathrm{Na}_{2} \mathrm{SO}_{4}$ and concentrated in vacuo to give a solid product. The title compounds were obtained by recrystallization from ethanol or ethyl acetate.

2-Methoxy-N-(2-(2-(4-(4-methylpiperazin-1-yl)phenylamino)-2-oxoethylthio)benzo[d]thiazol-6-yl)benzamide (1d). Off-white solid. Yield: $76 \mathrm{mg}, 75.47 \%$. m.p. 172.1-172.4 ${ }^{\circ} \mathrm{C} .{ }^{1} \mathrm{H}-\mathrm{NMR}$ (DMSO-d 6 ) $\delta: 2.10$ (s, 3H), $2.22(\mathrm{t}, 4 \mathrm{H}, J=4.4 \mathrm{~Hz}), 3.08(\mathrm{t}, 4 \mathrm{H}, J=4.8 \mathrm{~Hz}), 3.91(\mathrm{~s}, 3 \mathrm{H}), 4.35(\mathrm{~s}, 3 \mathrm{H}), 6.91(\mathrm{~d}, 2 \mathrm{H}$, $J=8.8 \mathrm{~Hz}), 7.09$ (t, 1H, $J=7.2 \mathrm{~Hz}), 7.20(\mathrm{~d}, 1 \mathrm{H}, J=8.4 \mathrm{~Hz}), 7.48(\mathrm{~d}, 2 \mathrm{H}, J=8.4 \mathrm{~Hz}), 7.53(\mathrm{t}, 1 \mathrm{H}$, 
$J=8 \mathrm{~Hz}), 7.67(\mathrm{q}, 2 \mathrm{H}, J=8.8 \mathrm{~Hz}), 7.80(\mathrm{~d}, 1 \mathrm{H}, J=8.4 \mathrm{~Hz}), 8.55(\mathrm{~s}, 1 \mathrm{H}), 10.22(\mathrm{~s}, 1 \mathrm{H}), 10.36(\mathrm{~s}, 1 \mathrm{H})$; ESI-MS $(m / z, \%): 548.0(\mathrm{M}+\mathrm{H})^{+}$.

N-(2-(2-(4-Chlorobenzylamino)-2-oxoethylthio)benzo[d]thiazol-6-yl)-4-(4-methylpiperazin-1-yl)-benzamide (1e). Yellow solid. Yield: $184 \mathrm{mg}, 65.36 \%$. m.p. 177.8-179.2 ${ }^{\circ} \mathrm{C} .{ }^{1} \mathrm{H}-\mathrm{NMR}$ (DMSO-d 6 ) $\delta: 2.09$ (s, $3 \mathrm{H}), 2.45(\mathrm{t}, 4 \mathrm{H}, J=4.4 \mathrm{~Hz}), 3.30(\mathrm{t}, 4 \mathrm{H}, J=4.8 \mathrm{~Hz}), 4.19(\mathrm{~s}, 2 \mathrm{H}), 4.31$ (d, 2H, $J=6 \mathrm{~Hz}), 7.03(\mathrm{~d}, 2 \mathrm{H}$, $J=8.8 \mathrm{~Hz}), 7.28(\mathrm{~d}, 2 \mathrm{H}, J=8.8 \mathrm{~Hz}), 7.32(\mathrm{~d}, 2 \mathrm{H}, J=8.4 \mathrm{~Hz}), 7.76(\mathrm{~s}, 2 \mathrm{H}), 7.89(\mathrm{~d}, 2 \mathrm{H}$, $J=8.8 \mathrm{~Hz}), 8.52(\mathrm{~s}, 1 \mathrm{H}), 8.85(\mathrm{t}, 1 \mathrm{H}, J=6 \mathrm{~Hz}), 10.17(\mathrm{~s}, 1 \mathrm{H})$; ESI-MS $(\mathrm{m} / \mathrm{z}, \%): 566.2(\mathrm{M}+\mathrm{H})^{+}$.

2-Methoxy-N-(2-(2-(4-(4-methylpiperazin-1-yl)phenylamino)-2-oxoethylthio)-1H-benzo[d] imidazol-6yl)benzamide (1f). Faint yellow solid. Yield: $90 \mathrm{mg}, 81.08 \%$. m.p. $132.3-132.6{ }^{\circ} \mathrm{C} .{ }^{1} \mathrm{H}-\mathrm{NMR}$ (DMSO-d $\left.\mathrm{d}_{6}\right)$ $\delta: 2.21(\mathrm{~s}, 3 \mathrm{H}), 2.43(\mathrm{t}, 4 \mathrm{H}, J=4 \mathrm{~Hz}), 3.06(\mathrm{t}, 4 \mathrm{H}, J=4 \mathrm{~Hz}), 3.90(\mathrm{~s}, 3 \mathrm{H}), 4.21(\mathrm{~s}, 2 \mathrm{H}), 6.88(\mathrm{~d}, 2 \mathrm{H}$, $J=8.8 \mathrm{~Hz}), 7.07(\mathrm{t}, 1 \mathrm{H}, J=7.2 \mathrm{~Hz}), 7.18(\mathrm{~d}, 1 \mathrm{H}, J=8 \mathrm{~Hz}), 7.30(\mathrm{q}, 1 \mathrm{H}, J=8.4 \mathrm{~Hz}), 7.43(\mathrm{t}, 3 \mathrm{H}$, $J=8.8 \mathrm{~Hz}), 7.50(\mathrm{t}, 1 \mathrm{H}, J=7.6 \mathrm{~Hz}), 7.64(\mathrm{~d}, 1 \mathrm{H}, J=7.2 \mathrm{~Hz}), 8.07(\mathrm{~d}, 1 \mathrm{H}, J=33.2 \mathrm{~Hz}), 10.08(\mathrm{~d}, 1 \mathrm{H}$, $J=32.8 \mathrm{~Hz}), 10.27(\mathrm{~s}, 1 \mathrm{H}), 12.60(\mathrm{~s}, 1 \mathrm{H})$; ESI-MS $(\mathrm{m} / \mathrm{z}, \%): 531.3(\mathrm{M}+\mathrm{H})^{+}$.

2-Methoxy-N-(2-(2-(4-(4-methylpiperazin-1-yl)phenylamino)-2-oxoethylthio)benzo[d]oxazol-6-yl)-benzamide (1g). Yellow solid. Yield: $100 \mathrm{mg}, 75.75 \%$. m.p. 210.4-210.8 ${ }^{\circ} \mathrm{C} .{ }^{1} \mathrm{H}-\mathrm{NMR}$ (DMSO-d 6 ) $\delta: 2.24$ (s, $3 \mathrm{H}), 2.40(\mathrm{t}, 4 \mathrm{H}, J=4.4 \mathrm{~Hz}), 3.14(\mathrm{t}, 4 \mathrm{H}, J=4.8 \mathrm{~Hz}), 3.89(\mathrm{~s}, 3 \mathrm{H}), 4.23(\mathrm{~s}, 2 \mathrm{H}), 6.91(\mathrm{~d}, 2 \mathrm{H}$, $J=8.8 \mathrm{~Hz}), 7.09(\mathrm{t}, 1 \mathrm{H}, J=7.2 \mathrm{~Hz}), 7.20(\mathrm{~d}, 1 \mathrm{H}, J=8.4 \mathrm{~Hz}), 7.48(\mathrm{~d}, 2 \mathrm{H}, J=8.4 \mathrm{~Hz}), 7.53(\mathrm{t}, 1 \mathrm{H}$, $J=8 \mathrm{~Hz}), 7.67(\mathrm{q}, 2 \mathrm{H}, J=8.8 \mathrm{~Hz}), 7.80(\mathrm{~d}, 1 \mathrm{H}, J=8.4 \mathrm{~Hz}), 8.26(\mathrm{~s}, 1 \mathrm{H}), 9.98(\mathrm{~s}, 1 \mathrm{H}), 10.29(\mathrm{~s}, 1 \mathrm{H})$; ESI-MS (m/z, \%): $532.2(\mathrm{M}+\mathrm{H})^{+}$.

\subsection{Cell Culture}

Cell lines including HepG2, Hela, Skov-3, A375 and A431 were maintained in Dulbecco's modified Eagle medium (DMEM) containing 10\% fetal bovine serum (FBS), penicillin (100 U/mL) and streptomycin (10 mg/L). Cell lines including HCT116, PC-9, A549 and H460 were maintained in RPMI 1640 containing 10\% fetal bovine serum (FBS), penicillin (100 U/mL) and streptomycin $(10 \mathrm{mg} / \mathrm{L})$. Cells were grown in a $5 \% \mathrm{CO}_{2}$ incubator at $37{ }^{\circ} \mathrm{C}$.

\subsection{Cell Proliferation Assay (MTT Assay)}

Cells $\left(2 \times 10^{3} /\right.$ well $)$ were seeded in 96 -well plates and cultured for $24 \mathrm{~h}$, followed by compounds which dissolved in dimethylsulfoxide (DMSO) treatment for $48 \mathrm{~h}$. Ten microliters of $10 \mathrm{mg} / \mathrm{mL}$ MTT was added and cultured for $4 \mathrm{~h}$, the medium was removed and $150 \mu \mathrm{L}$ of DMSO was added to dissolve formazan crystals. Absorbance was measured at $570 \mathrm{~nm}$ using an SpectraMAX M5 microplate spectrophotometer (Molecular Devices). The proliferation inhibitory effects of the compounds on cancer cells were expressed as $\mathrm{IC}_{50}$.

\subsection{Immunofluorescence}

Cells $\left(1 \times 10^{5}\right)$ were plated in 6-well plates. Following drug treatment for $24 \mathrm{~h}$, cells were washed with PBS, punched by Triton X-100. Subsequently cells were probed by the primary antibodies. Then 
cells were incubated with the secondary antibody for $30 \mathrm{~min}$ at room temperature and examined under a fluorescence microscope [8].

\section{Conclusions}

In this paper, five novel benzothiazole-2-thiol, benzimidazole-2-thiol and benzoxazole-2-thiol derivatives were synthesized for lead optimization, and their in vitro antitumor activity was evaluated. To our delight, compounds $\mathbf{1 d}$, $\mathbf{1 f}$ and $\mathbf{1 g}$ showed comparable antitumor activities and better solubility compared with the lead compound 1a. In a preliminary antitumor activity mechanism study, we found a novel phenomenon, that is, cytosolic vacuolization after treatment with these compounds which was not induced by 1a. Thus, it indicates that compounds 1d, 1f and $\mathbf{1 g}$ might possess different anticancer mechanism, which deserves further study.

\section{Acknowledgements}

We thank the Analytical and Testing Center of Sichuan University for NMR measurements.

\section{References and Notes}

1. The Global Burden of Disease: 2004 Update; World Health Organization: Geneva, Switzerland, 2008.

2. Wang, Z.; Shi, X.-H.; Wang, J.; Zhou, T.; Xu, Y.-Z.; Huang, T.-T.; Li, Y.-F.; Zhao, Y.-L.; Yang, L.; Yang, S.-Y.; et al. Synthesis, structure-activity relationships and preliminary antitumor evalutation of benzothiazole-2-thiol derivatives as novel apoptosis inducers. Bioorg. Med. Chem. Lett. 2011, 21, 1907-1101.

3. Capdeville, R.; Buchdunger, E.; Zimmermann, J.; Matter, A. Glivec (STI571, imatinib), a rationaly developed, targeted anticancer drug. Nat. Rev. Drug Discov. 2002, 1, 493-502.

4. Baraldi, P.G.; Preti, D.; Tabrizi, M.A.; Fruttarolo, F.; Saponaro, G.; Baraldi, S.; Romagnoli, R.; Moorman, AR.; Gessi, S.; Varani, K.; Borea, P.A. N(6)-[(hetero)aryl/(cyclo)alkyl-carbamoylmethoxy-phenyl]-(2-chloro)-5'- $N$-ethylcarboxamido-adenosines: The first example of adenosinerelated structures with potent agonist activity at the human $\mathrm{A}(2 \mathrm{~B})$ adenosine receptor. Bioorg. Med. Chem. 2007, 15, 2514-2527.

5. Mussom, D.L.; Cochran, F.R.; Kelley, J.L.; Mclean, E.W.; Selph, J.L.; Rigdon, G.C.; Orr, G.F.; Davis, R.G.; Cooper, B.R.; Styles, V.L.; et al. Indanylidenes. 1. Design and synthesis of (E)-2-(4, 6-difluoro-1-indanylidene)acetamide, a potent, centrally acting muscle relaxant with antiinflammatory and analgesic activity. J. Med. Chem. 2003, 46, 399-408.

6. Mimnaugh, E.G.; Xu, W.; Vos, M. Simultaneous inhibition of hsp 90 and the proteasome promotes protein ubiquitination, causes endoplasmic reticulum-derived cytosolic vacuolization, and enhances antitumor activity. Mol. Cancer Ther. 2004, 3, 551-566.

7. Wynne, G.M.; Wren, S.P.; Johnson, P.D.; Price, P.D.; De Moor, O.; Nugent, G.; Storer, R.; Pye, R.J.; Dorgan, C.R. Treatment of duchenne muscular dystrophy. WO 2007/091106 A2, 16 August 2007. 
8. Kanzawa, T.; Kondo, Y.; Ito, H.; Kondo, S.; Germano, I. Induction of autophagic cell death in malignant glioma cells by arsenic trioxide. Cancer Res. 2003, 63, 2103-2108.

Sample Availability: Samples of the compounds 1c-g are available from the authors.

(C) 2012 by the authors; licensee MDPI, Basel, Switzerland. This article is an open-access article distributed under the terms and conditions of the Creative Commons Attribution license (http://creativecommons.org/licenses/by/3.0/). 